Submitted, accepted and published by:

Fuel 114 (2013) 106-113

\title{
Optimum temperature for sulphur retention in fluidised beds working under oxy-fuel combustion conditions
}

\author{
L.F. de Diego, A. Rufas, F. García-Labiano, M. de las Obras-Loscertales, A. Abad, P. \\ Gayán, J. Adánez. \\ Dept. Energy and Environment, Instituto de Carboquímica (ICB-CSIC) \\ Miguel Luesma Castán 4, 50018 Zaragoza. Spain \\ Corresponding author: Idediego@icb.csic.es
}

Keywords: Oxy-fuel combustion, $\mathrm{SO}_{2}$ retention, limestone, fluidised bed.

\begin{abstract}
Oxy-fuel combustion is one of the leading options for power generation with $\mathrm{CO}_{2}$ capture. The process consists of burning the fuel with a mixture of nearly pure oxygen and a $\mathrm{CO}_{2}$-rich recycled flue gas, resulting in a product flue gas from the boiler containing mainly $\mathrm{CO}_{2}$ and $\mathrm{H}_{2} \mathrm{O}$. Among the possible boiler types, fluidised bed combustors are very appropriate for the oxy-fuel process because they allow the in-situ desulphurisation by feeding Ca-based sorbents into the combustor.

In this work, the effect of the temperature of the combustor on the retention of the $\mathrm{SO}_{2}$ generated in the combustion of two coals with very different sulphur content (a lignite and an anthracite) has been studied. The experimental facility used was a bubbling fluidised bed (BFB) combustor of $\sim 3 \mathrm{~kW}_{\text {th }}$. Tests were conducted under oxy-fuel combustion mode and also under enriched-air combustion mode for comparison reasons. A Spanish limestone “Granicarb” was used as Ca-based sorbent for sulphur retention. The temperatures tested were between 800 and $970{ }^{\circ} \mathrm{C}$ using $\mathrm{Ca} / \mathrm{S}$ molar ratios between 0 and 3 .

It was found that in BFB combustors operating under oxy-fuel combustion conditions the optimum temperature to achieve the highest sulphur retention was $900-925{ }^{\circ} \mathrm{C}$, whereas operating with enriched air the optimum combustion temperature was 850-870 ${ }^{\circ} \mathrm{C}$. Working at the optimum temperature, the $\mathrm{SO}_{2}$ retentions were lower in oxy-fuel
\end{abstract}


combustion than in enriched air combustion conditions. It was also observed that working with lignite there was $10-15 \%$ of sulphur retention by coal ashes, however, working with anthracite the sulphur retention by coal ashes was negligible. This finding was independent of the combustion mode used, oxy-fuel or enriched air.

\section{Introduction}

The emission of gases into the atmosphere from burning fossil fuels, mainly coal, in large power plants causes important environmental problems. The $\mathrm{CO}_{2}$ produced in combustion process has been recognised as one of the major contributors to the build-up of greenhouse gases in the atmosphere and, in addition, sulphur in coal is oxidised to $\mathrm{SO}_{2}$, which contributes to acid rain formation.

The capture and storage of $\mathrm{CO}_{2}$, emitted in large quantities from power plants, is considered an option to be explored in the medium term for reducing $\mathrm{CO}_{2}$ levels released to the atmosphere. Oxy-fuel combustion is one of the possibilities under investigation within the different options for $\mathrm{CO}_{2}$ capture [1-3]. This technology uses for combustion pure $\mathrm{O}_{2}$ (instead of air used in conventional combustion) mixed with $\mathrm{CO}_{2}$-rich recycled flue gas, and so, the flue gas stream from the boiler finally produced is highly concentrated on $\mathrm{CO}_{2}$. After condensing water and a cleaning step, the $\mathrm{CO}_{2}$ can be stored.

Among the possible boiler types, fluidised bed (FB) combustors are very appropriate for the oxy-fuel process because they allow the in-situ desulphurisation of the flue gas by feeding Ca-based sorbents into the combustor, such as limestone or dolomite. This could be an advantage since sulphur containing species mean a risk of corrosion and could have impacts in the furnace, during ash collection, $\mathrm{CO}_{2}$ compression, transport and storage [4,5]. Other well known advantages are the possibility of burning a wide range of fuels and the relatively low NOx emissions achieved [6-7]. It is also believed that oxy-fuel circulating fluidised bed (CFB) combustors could be an important candidate for new coal fired power plants, mainly because the circulation of solids in the combustor can help to an effective control of the temperature [5-11]. This will permit the use of high oxygen concentrations in the combustor, thus reducing the area of the CFB combustor, as well as the amount of recycled flue gas, thus reducing the size of some subsequent equipments and power consumption [10]. Other important advantage 
is the efficiency improvement, mainly due to the strong mixing in the furnace and longer residence times of solids that allows a good carbon burnout.

The development of the oxy-fuel combustion technology in CFB combustor is currently growing. Alstom [10], VTT and Foster Wheeler [11], Metso [12], Czestochowa University of Technology [7], and Canmet Energy [5,8,9,13] have experimented in oxyfuel combustion with CFB combustors at scales up to $4 \mathrm{MW}_{\text {th }}$. The Fundación Ciuden [14] in Spain is developing two plants able to operate from conventional air combustion to oxy-fuel combustion. One is a $20 \mathrm{MW}_{\text {th }}$ PC boiler and the other is a CFB combustor of $15 \mathrm{MW}_{\text {th }}$ operating in air-mode and $30 \mathrm{MW}_{\text {th }}$ operating in oxy-mode. The research group of Canmet Energy [8-9] is involved in testing a CFB combustor of $100 \mathrm{~kW}_{\text {th }}$ with flue gas recycle. Operating at $\sim 850{ }^{\circ} \mathrm{C}$, they found lower sulphation in oxy-fuel combustion than in air combustion conditions, but the sulphation improved working with a petroleum coke by increasing the operation temperature, that is, changing from direct to indirect sulphation. However, the same effect was not confirmed working with coals. Recently this group has successfully converted and operated a conventional 0.8 $\mathrm{MW}_{\text {th }}$ pilot-plant to oxy-fuel firing $[5,13]$. Their results strongly support the view that this technology offers all of the advantages of air-fired CFB. However, the test experiences showed that operating the pilot-scale unit over a long period under oxy-fuel mode led to enhanced corrosion due to higher sulphur concentrations in the flue gas [5]. $\mathrm{SO}_{2}$ concentration under oxy-fuel mode was up to four times higher compared to air firing mode. They concluded that limestone performance for sulphur removal was impacted by the combustion mode, and that this impact depended on fuel characteristics as well as on combustion temperature.

Our research group have recently carried out several tests in a thermogravimetric analyser (TGA) and in a batch fluidised bed reactor to analyse the behaviour of limestones for $\mathrm{SO}_{2}$ retention under oxy-fuel operating conditions [15-16]. We found that the major effect of increasing the $\mathrm{CO}_{2}$ concentration in the reacting gas was to shift the $\mathrm{CaCO}_{3}$ decomposition to $\mathrm{CaO}$ until a higher temperature. The higher temperature needed to work in conditions of indirect sulphation with increasing $\mathrm{CO}_{2}$ contents had a negative influence on the sulphation conversion reached by the limestones. It was concluded that the optimum temperature for sulphur retention in oxy-fuel combustion mode in FB reactors was incremented up to $\sim 925{ }^{\circ} \mathrm{C}$ from the $850{ }^{\circ} \mathrm{C}$ normally used at conventional air combustion conditions. This conclusion seems in good agreement with 
the results found by Canmet Energy working in its CFB combustors [5,9]. However, more work should be carried in continuous fluidised bed reactors to confirm this conclusion.

The objective of this work was to determine the optimum operating temperature to achieve the maximum sulphur retention in fluidised bed reactors working under oxyfuel operating conditions. Tests were carried out in a continuous bubbling fluidised bed (BFB) combustor $\left(\sim 3 \mathrm{~kW}_{\text {th }}\right)$ operating with limestone under calcining or non calcining conditions. Two coals of different rank and sulphur content were used. The effect of $\mathrm{Ca} / \mathrm{S}$ molar ratio with respect to the sorbent sulphation process was also analysed.

\section{Experimental section}

\subsection{Materials}

Two Spanish coals, an anthracite and a lignite with a high sulphur content, were selected for this study. Both coals were crushed and sieved, and the particle size in the range of 0.2-1.2 mm was used. Table 1 gives the proximate and ultimate analyses of the coals. Sulphur in coal can exist in both inorganic and organic forms. The inorganic sulphur is mostly pyrite and/or marcasite, together with small amounts of sulphates depending on the level of oxidation of the coal. The organic sulphur exists either in aromatic rings or in aliphatic functional groups. The distribution between organic and pyritic sulphur depends on the rank and total sulphur content of the coal [17]. The release of the sulphur to form $\mathrm{SO}_{2}$ in the oxy-fuel combustion process can depend on the sulphur distribution. So, it is also included in Table 1 the different forms of the sulphur and the composition of the coal ashes. In this case, all the sulphur present in the anthracite was as pyritic form meanwhile sulphur present in lignite was distributed in three forms. The analysis of the ashes shows that both coals contained some $\mathrm{CaO}$, which could contribute to the reduction of the $\mathrm{SO}_{2}$ emissions.

For sulphur capture tests, a high purity Spanish limestone "Granicarb” (97.1 wt.\% $\mathrm{CaCO}_{3}$ ) was used as Ca-based sorbent. Table 2 gives the analysis of the Granicarb limestone. Particle size of the limestone was in the range of $0.3-0.5 \mathrm{~mm}$. The porosities of the raw and after calcination sorbent were $3.7 \%$ and $49 \%$, respectively. 
In addition, inert silica sand of size 0.2-0.6 mm was fed together with the coals and the limestone during all the tests to decrease the residence time of the sorbent in the fluidised bed reactor, as it will be commented later.

\subsection{Experimental installation}

The experimental installation of $\sim 3 \mathrm{~kW}_{\text {th }}$ consisted of a fluidised bed combustor and different auxiliary systems for gas supply, solid feeding, solid recovering, and gas analysis. Figure 1 shows a schematic diagram of the installation.

The combustor consisted of a stainless steel reactor of $10 \mathrm{~cm}$ i.d. and $60 \mathrm{~cm}$ height and a freeboard of $15 \mathrm{~cm}$ i.d. and $50 \mathrm{~cm}$ height. The height of solid in the BFB was maintained constant at $40 \mathrm{~cm}$. A heat exchanger located inside the bed allowed us the perfect control of temperature. This heat exchanger could be moved vertically through the reactor, modifying the contact surface inside the bed and extracting the needed heat from the combustor to reach the desired temperature.

The reactant gases, air, $\mathrm{CO}_{2}$, and $\mathrm{O}_{2}$, were supplied from bottles by mass-flow controllers to simulate typical gas compositions entering into the reactor in oxy-fuel combustion conditions. These gases were fed into the reactor through a distributor plate. A linear gas velocity of $40 \mathrm{~cm} / \mathrm{s}$ (calculated at $850{ }^{\circ} \mathrm{C}$ ) at the inlet of the bed was used during all the tests. An air pre-heater allowed introducing hot air inside the reactor during the start-up of the plant.

The solids were fed to the reactor by means of water-cooled screw feeders located just above the distributor plate. To assure a constant $\mathrm{Ca} / \mathrm{S}$ molar ratio, coal and sorbent were fed together by means of two screw feeders in series: the first one controlled the coal/sorbent feeding rate and the second one introduced the solid mixture as quick as possible into the bed to avoid the coal pyrolysis and the plugging of the pipe. Other screw feeder controlled the sand fed to the combustor.

The flue gas stream leaving the combustor passed through a high efficiency cyclone to recover the elutriated solids, and then was sent to the stack. The gas composition at the exit of the combustor was analysed continuously after water condensation by on-line gas analysers. $\mathrm{CO}_{2}, \mathrm{CO}$ and $\mathrm{SO}_{2}$ concentrations were measured in a Non-Dispersive 
Infra-Red analyser (NDIR, Siemens/Ultramat 23), and $\mathrm{O}_{2}$ concentration in a paramagnetic analyser (Siemens/Oxymat 6).

The facility was equipped with pressure sensors and thermocouples to know the pressure drop and temperatures along the installation. General process data (temperatures, pressures, mass flow of gases, gas composition, etc.) were continuously recorded by a computer.

\subsection{Procedure}

For star-up, the bed was filled with $\sim 1.8 \mathrm{~kg}$ of sand. Figure 2 shows the typical evolution of temperature and gas composition during the start-up of the installation until reaching stable operating conditions. Hot air was introduced through the gas pre-heater to heat the bed up to the ignition temperature of the coal $\left(\sim 400{ }^{\circ} \mathrm{C}\right)$. At this temperature, the coal feed started and the bed temperature rose rapidly due to the combustion of the coal. Neither sand nor sorbent was fed during this step. During this step, $\mathrm{O}_{2}$ concentration decreased and $\mathrm{CO}_{2}, \mathrm{CO}$, and $\mathrm{SO}_{2}$ appeared as combustion products. $\mathrm{CO}$ concentration was high at the lowest temperatures, due to the bad combustion, but as the temperature went on the $\mathrm{CO}$ concentration decreased. When the temperature set point was reached and the initial charge of coal (without limestone) spent, the sand and the coal/limestone mixture were fed into the bed, the preheating system was turn off, the air was replaced by the desired $\mathrm{O}_{2} / \mathrm{CO}_{2}$ or $\mathrm{O}_{2} / \mathrm{N}_{2}$ mixture, and the heat exchanger was introduced into the bed to control the temperature. The total time for the start-up of the plant was about 3-4 hours. Once stable operating conditions were reached, these conditions were maintained until reaching steady state operation for $\mathrm{SO}_{2}$ retention. This aspect will be commented in detail later.

The $\mathrm{SO}_{2}$ retention (SR) was calculated by equation (1) as the molar fraction of sulphur retained by the bed solids with respect to the sulphur fed into the bed.

$$
\mathrm{SR}(\%)=\frac{\left(\mathrm{F}_{0, \text { coal }} \mathrm{X}_{\mathrm{S}, \text { coal }} / \mathrm{M}_{\mathrm{SO} 2}\right)-\mathrm{Q} \cdot \mathrm{C}_{\mathrm{SO} 2}}{\mathrm{~F}_{0, \text { coal }} \mathrm{X}_{\mathrm{S} \text {, coal }} / \mathrm{M}_{\mathrm{SO} 2}} .100
$$

being $\mathrm{F}_{0 \text {,coal }}$ the feeding coal rate, $\mathrm{x}_{\mathrm{S} \text {, coal }}$ the coal sulphur content, $\mathrm{M}_{\mathrm{SO} 2}$ the molecular weight of $\mathrm{SO}_{2}, \mathrm{C}_{\mathrm{SO} 2}$ the $\mathrm{SO}_{2}$ concentration in the flue gas, and $\mathrm{Q}$ the gas flow rate at the exit of the reactor. The $\mathrm{SO}_{2}$ concentration was considered as an average value of those measured along the whole duration of the test in steady state conditions. Q was 
calculated by means of a mass balance, considering the coal and gas flow rates fed to the combustor and the flue gas composition.

\subsection{Steady state conditions for $\mathrm{SO}_{2}$ retention.}

An important feature of the tests carried out in continuous units is the certainty that the results are obtained under steady state conditions. In our installation, considering the fluidised bed dimensions, the coal and limestone feeding rates (with a $\mathrm{Ca} / \mathrm{S}$ molar ratio of 3 and without feeding sand), and assuming that the coal ashes are not elutriated out of the combustor, the mean residence time of solids in the bed was estimated by equation (2) to be about 7 hours when operating with anthracite and 4 hours with the lignite.

$t_{R}(h)=\frac{W_{\text {bed }}}{F_{\text {ash }}+F_{\text {limestone }}}$

Of course, the mean residence time of non-elutriable solids will be higher when the $\mathrm{Ca} / \mathrm{S}$ molar ratio would be lower than 3 and because an important fraction of ash will be elutriated out of the combustor and collected by the cyclone (this fact was observed in the experiments). So, mean residence times between 5 and 20 hours, or even higher, would be normal for typical tests in our installation.

To be sure that steady state conditions have been reached, it is considered that the weight of solids fed to the bed should be at least 2-2.5 times the weight of solids existing in the bed, which gives operating times of 10-50 hours, out of our experimental possibilities. To reduce the mean residence time of the solids inside the fluidised bed up to about 2 hours, $0.9 \mathrm{~kg} / \mathrm{h}$ of sand was fed into the reactor in all of the tests. In this way, after reaching stable conditions, the steady state for $\mathrm{SO}_{2}$ retention was reached in 4-5 hours and maintained at least for 1 hour for each experimental data.

\section{Results}

Coal combustion tests with and without limestone addition were carried out in a BFB combustor working in oxy-fuel combustion conditions with oxygen concentrations at the inlet of 27 and 35 vol.\% $\mathrm{O}_{2}$. In addition, similar experiments were also carried out under enriched air conditions to know the effect of the reaction atmosphere. 
Tables 3 and 4 summarize the experiments carried out with the two coals including the operating conditions (temperature, $\mathrm{Ca} / \mathrm{S}$ molar ratio, and $\mathrm{O}_{2}$ concentration), as well as the $\mathrm{O}_{2}$ in the flue gas and the $\mathrm{SO}_{2}$ emissions measured in each case. These data correspond to the average values recorded during at least 1 hour working under steady state operation, which gives a total of about 50 hours in steady state and about 300 hours of total continuous operation in the plant (including the time to reach the steady state).

To calculate both the SR and the power developed by the facility, a combustion efficiency of $100 \%$ has been considered. This simplification was made because the carbon combustion efficiencies determined by solid analysis were always $>99 \%$ working with the lignite and $>98 \%$ working with the anthracite. These combustion efficiencies were determined in the tests carried out without limestone addition taking into account the carbon fed to the combustor and the losses of carbon in the solids collected in the cyclone and in the solids collected in the drainage deposit.

\subsection{Influence of temperature.}

In practice, FB combustors are usually operated in the $800-950{ }^{\circ} \mathrm{C}$ range, under overall oxidising conditions [18]. Some researchers [19-20] have found that the optimum temperature for sulphur retention was nearly $850{ }^{\circ} \mathrm{C}$ under conventional air combustion in FB combustors. These operating conditions are characterised by low $\mathrm{CO}_{2}$ concentrations in the flue gas (up to $16 \%$ ). However, the $\mathrm{CO}_{2}$ concentration in oxy-fuel operating conditions is significantly higher than in air combustion, up to $90 \%$, which will affect to the Ca-based sorbent behaviour inside the bed.

When a Ca-based sorbent is added to a FB combustor, temperature is one of the most important parameters affecting the $\mathrm{SO}_{2}$ retention process because sorbent calcination is highly dependent on the temperature and $\mathrm{CO}_{2}$ concentration through the thermodynamic equilibrium curve of $\mathrm{CaCO}_{3}$ calcination, as it can be observed in Figure 3 .

The conditions existing in FB combustors during conventional combustion with air lead to a previous sorbent calcination (R1) and to the sulphation of calcines (R2), i.e. indirect sulphation:

$$
\mathrm{CaCO}_{3} \rightleftharpoons \mathrm{CaO}+\mathrm{CO}_{2}
$$




$$
\mathrm{CaO}+\mathrm{SO}_{2}+1 / 2 \mathrm{O}_{2} \rightleftharpoons \mathrm{CaSO}_{4}
$$

In oxy-fuel combustion, $\mathrm{CO}_{2}$ concentration in the flue gas may be enriched up to values as high as $90 \%$. Therefore, the sorbent can be surrounded by $\mathrm{CO}_{2}$ concentrations ranging from 40 to $90 \%$ during their stage in the $\mathrm{FB}$ reactor. Under so high $\mathrm{CO}_{2}$ concentrations, the sorbent can behave in two ways depending on the temperature (see Figure 3). At $850{ }^{\circ} \mathrm{C}$, the sulphur retention will be produced under direct sulphation (R3), being necessary higher temperatures to operate under indirect sulphation (R1 and $\mathrm{R} 2)$.

$$
\mathrm{CaCO}_{3}+\mathrm{SO}_{2}+1 / 2 \mathrm{O}_{2} \rightleftharpoons \mathrm{CaSO}_{4}+\mathrm{CO}_{2}
$$

To analyse the effect of temperature on SR, several tests were carried out maintaining constant the $\mathrm{Ca} / \mathrm{S}$ molar ratio and the $\mathrm{O}_{2}$ concentration at the inlet of the reactor. Tables 3 and 4 give the $\mathrm{SO}_{2}$ emissions measured in the tests and Figure 4 shows the effect of temperature on SR for the two coals working with enriched air and in oxy-fuel combustion conditions.

Working with enriched air, the SR increased with increasing temperature up to a maximum of $850-870{ }^{\circ} \mathrm{C}$ for both coals and then, a further increase in temperature caused a decrease in SR values. These results are in accordance with other authors who affirm the existence of a maximum sulphur capture efficiency at about $850{ }^{\circ} \mathrm{C}$ working in atmospheric FB combustors systems under air combustion conditions [18]. Lin [21] has summarised several of the reasons proposed as responsible of this maximum which, include: sorbent sintering at high temperatures, resulting in lower porosity and surface area, hence reducing the overall conversion of the limestone; $\mathrm{SO}_{2} / \mathrm{SO}_{3}$ equilibrium determines the maximum, with higher temperatures reducing the availability of $\mathrm{SO}_{3}$ for reaction with $\mathrm{CaO}$; and high temperatures enhances sulphation rate which causes small pores to become blocked preventing the entry of $\mathrm{SO}_{2} / \mathrm{SO}_{3}$ to the inner part of the calcined limestone particle.

Comparing the results obtained working with air and under oxy-fuel operating conditions, it is clear that oxy-fuel combustion conditions shift the maximum in SR from $\sim 850$ to $900-925^{\circ} \mathrm{C}$. These results are in good agreement with the results obtained in previous works of our research group where the sulphur retention capacity of the limestone "Granicarb” was analysed in a TGA and in a batch FB reactor under different operating conditions [15-16]. In these works, it was found that the effect of the 
temperature was different for the direct and indirect sulphation reactions. In direct sulphation or non-calcining conditions, the sulphation reaction rate rose with increasing the temperature (until reach calcining conditions). On the contrary, in conditions of indirect sulphation or calcining conditions, the sulphation reaction rate increased with increasing the temperature up to $900-925{ }^{\circ} \mathrm{C}$ and then decreased. The sulphation conversions achieved under indirect sulphation were always higher than those achieved under direct sulphation. As shown in Figure 3, the high partial pressure of $\mathrm{CO}_{2}$ in oxyfuel shifts the decomposition of $\mathrm{CaCO}_{3}$ to higher temperatures. Therefore, at temperature of $850{ }^{\circ} \mathrm{C}$ under oxy-fuel combustion leads to direct sulphation, being necessary temperatures higher than $900{ }^{\circ} \mathrm{C}$ to be indirect sulphation. As a consequence, the maximum sorbent conversion was reached at temperatures about $900-925^{\circ} \mathrm{C}$.

It can be also seen in Figure 4 that operating at the optimal temperature for each case, enriched air or oxy-fuel, the SR obtained in oxy-fuel combustion was lower than that obtained in enriched air combustion conditions, probably because the higher temperature needed for the sorbent calcination caused an increase of the sinterisation of the limestone.

Figure 5 shows a comparison between the SR obtained working at the same operating conditions with the lignite and the anthracite. It can be observed that the behaviour of the limestone was qualitatively similar with both coals, but higher SR values, and so higher limestone sulphation conversions, were achieved working with the lignite. It has to be noted that lignite and anthracite have very different sulphur content, being much higher that of lignite (see Table 1). Previous studies carried out under oxy-fuel combustion conditions in a TGA [15] and in a batch FB reactor [16] demonstrated that the sulphation conversion of the sorbent increased as the $\mathrm{SO}_{2}$ concentration increased. The higher $\mathrm{SO}_{2}$ concentration present in the $\mathrm{FB}$ combustor during lignite combustion was therefore the responsible of the higher SR values achieved in the plant with this coal.

\subsection{Influence of the $\mathrm{Ca} / \mathrm{S}$ molar ratio}

As it is well know, the utilisation of Ca-based sorbents for SR in FB boilers is not complete due to the pore blockage produced by $\mathrm{CaSO}_{4}$ formation. In the typical operating conditions used in FB combustors, the sulphation reaction usually takes place 
at the external surface and around the pores of the sorbent particles. Since the molar volume of $\mathrm{CaSO}_{4}$ is higher than the molar volume of $\mathrm{CaCO}_{3}$ or $\mathrm{CaO}$, the pores are blocked and the inner part of the particles remains essentially unsulphated [18]. This is usually valid for both direct and indirect sulphation. Therefore, an important parameter in the SR process is the $\mathrm{Ca} / \mathrm{S}$ molar ratio used in the combustor. This $\mathrm{Ca} / \mathrm{S}$ molar ratio has to be necessarily higher than 1 in order to achieve a significant $\mathrm{SO}_{2}$ retention.

Figure 6 compares the SR achieved working with the lignite and the anthracite under oxy-fuel operating conditions at different $\mathrm{Ca} / \mathrm{S}$ molar ratios. As expected, an increase in the $\mathrm{Ca} / \mathrm{S}$ molar ratio produced a higher SR in all range of temperatures studied. The effect of the temperature was similar for the different $\mathrm{Ca} / \mathrm{S}$ molar ratios used, with maximum values at $900-925^{\circ} \mathrm{C}$.

When a Ca-based sorbent is fed into a combustor, the SR is normally attributed to the effect of the sorbent. However, it is known that not all the sulphur contained in the coal is emitted as $\mathrm{SO}_{2}$ either because it is already in sulphates form [17] or because coal ashes retain part of the $\mathrm{SO}_{2}$ released [22-24].

In this work, to know the real $\mathrm{SO}_{2}$ emissions derived from the combustion of the coals used, and to determine therefore the retention capacity of the coal ashes, combustion experiments without limestone addition $(\mathrm{Ca} / \mathrm{S}=0)$ were performed at different temperatures both in oxy and enriched air mode. The results obtained are shown in Figures 6 and 7. It can be observed that all the sulphur contained in the anthracite was emitted as $\mathrm{SO}_{2}$ during its combustion; however, a part of the sulphur contained in the lignite was not emitted as $\mathrm{SO}_{2}$. It seems that some of the $\mathrm{SO}_{2}$ generated during the combustion of the lignite was retained by its ashes, as it will be commented later. In addition, the SR produced by the coal ashes was almost the same working with enriched air and under oxy-fuel combustion conditions.

In the experiments carried out with the lignite, the SR produced by coal ashes was around $10-15 \%$, and slightly decreased with increasing the temperature. Taking into account the ash content and the $\mathrm{CaO}$ present in the coal ashes (see Table 1), the maximum SR that can be achieved by this $\mathrm{CaO}$ was calculated to be $18 \%$. Therefore, the utilization of this $\mathrm{CaO}$ was around $60-80 \%$, probably because part of the $\mathrm{CaO}$ was elutriated with the ashes out of the combustor. In the case of the anthracite, the SR produced by ashes was negligible. However, taking into account the ash content and the $\mathrm{CaO}$ present in the coal ashes in this coal, it was calculated that the maximun retention 
that can be achieved by this $\mathrm{CaO}$ would be $38 \%$. Therefore, it seems that the Ca present in the ashes is not in a form able to retain sulphur.

To analyse these results in more detail, ashes of both coals were produced in a muffle oven to study their capacity for SR. Samples of these ashes were introduced in a TGA, heated at $900{ }^{\circ} \mathrm{C}$, and then $\mathrm{CO}_{2} / \mathrm{O}_{2} / \mathrm{SO}_{2}$ was fed to simulate typical oxy-fuel operating conditions. The lignite ashes increased $10.5 \%$ in weight, whereas the anthracite ashes did not increase in weight. Both results are in accordance with the experimental results obtained in the BFB combustor.

\subsection{Effect of mean residence time of the limestone}

Some previous works on sorbent sulphation with long reaction times $[15,25]$ have demonstrated that the residual activity of the sorbents after pore plugging can be very important. However, as it was previously commented in the experimental section, an important feature of the tests carried out in this work was the certainty that the results were obtained under steady state conditions. For that, $0.9 \mathrm{~kg} / \mathrm{h}$ of sand was fed into the reactor in all of the tests. At these conditions, the mean residence time of the solids inside the fluidised bed was about 2 hours. However, average residence times in industrial FB combustors are clearly much higher than those used here, with values as high as 10-20 hours [26-28].

To analyse the effect on the SR of the mean residence time of the limestone in the combustor, two tests were carried out with both coals at $925^{\circ} \mathrm{C}$. For that, after reaching steady-state conditions with a mean residence time of the solids of 2 hours, the sand feeding was diminished from 0.9 to $0.2 \mathrm{~kg} / \mathrm{h}$ to increase the residence time of the solids inside the bed. Figure 8 shows the evolution of the $\mathrm{SO}_{2}$ concentration during these tests. It can be observed that an important decrease in the $\mathrm{SO}_{2}$ concentration was obtained as a consequence of the increase of the sorbent inventory in the bed as well as the increase of the residence time of the sorbent. However, it must be remarked that in these tests the steady-state was not achieved and no quantitative data can be obtained, although the trend is clear.

Figure 9 shows the sorbent sulphation conversion obtained in a TGA in a previous work as a function of the reaction time working with the Granicarb limestone ( $d p=0.3-0.5$ $\mathrm{mm}, 3000 \mathrm{vppm} \mathrm{SO}_{2}, 900{ }^{\circ} \mathrm{C}$, and 60 vol.\% $\mathrm{CO}_{2}$ ) [15]. Considering this plot as 
representative of the sorbent sulphation pattern exhibited by the limestone in the BFB combustor, an important increase in sorbent sulphation $(\Delta \mathrm{X})$ can be achieved by increasing the residence time as it would be usual in industrial FB combustors.

It can be concluded therefore that the results showed in this paper are very useful from a qualitatively point of view to determine the optimum operating temperature working under oxy-fuel combustion in FB with respect to the SR process. However, it is expected that the SR achieved in industrial units would be higher than those obtained in this work. So, tests of increasing solids residence time in the combustor under steady state conditions would be needed to confirm this issue.

\section{Conclusions}

Combustion tests were carried out in a $\sim 3 \mathrm{~kW}_{\text {th }}$ continuous BFB combustor with two coals and one limestone as sulphur sorbent under oxy-fuel and enriched-air combustion conditions to optimise the operating temperature with respect to the sulphur retention process in FB combustors.

It was found that sorbent calcination had a strong effect on $\mathrm{SO}_{2}$ retention under oxy-fuel combustion conditions. The $\mathrm{SO}_{2}$ retention was higher working at calcining (indirect sulphation) than at non-calcining (direct sulphation) operating conditions. The optimum FB combustor temperature from of point of view of SR shifted from $850-870{ }^{\circ} \mathrm{C}$ in combustion with enriched air to $900-925{ }^{\circ} \mathrm{C}$ in oxy-fuel combustion mode. Working at the optimum temperature for each combustion mode, the $\mathrm{SO}_{2}$ retentions obtained in oxy-fuel combustion were lower than those obtained under air combustion.

As it is obvious, an increase in the $\mathrm{Ca} / \mathrm{S}$ molar ratio produced an increase in $\mathrm{SO}_{2}$ retention in all range of temperatures. In addition, an important effect of coal ashes on $\mathrm{SO}_{2}$ retention was determined for the lignite, meanwhile the $\mathrm{SO}_{2}$ retention achieved by the anthracite ashes was negligible.

The results showed in this paper are very useful from a qualitatively point of view to determine the optimum operating temperature working under oxy-fuel combustion in $\mathrm{FB}$ with respect to the $\mathrm{SO}_{2}$ retention process. However, it is expected that the $\mathrm{SO}_{2}$ retention achieved in industrial units with longer residence time of solids would be higher than those obtained in this work. 


\section{Acknowledgements}

This work has been supported by Spanish Ministry of Science and Innovation (MICINN, Project: CTQ2008-05399/PPQ) and by FEDER. A. Rufas thanks CSIC for the JAE fellowship and M. de las Obras thanks MICINN for the FPI fellowship.

\section{References}

[1] Wall T, Liu Y, Spero C, Elliott L. An overview on oxyfuel coal combustion - State of the art research and technology development. Chem Eng Res Des 2009;87:10031016.

[2] Kanniche M, Gros-Bonnivard R, Jaud P, Valle-Marcos J, Amann JM, Bouallou C. Pre-combustion, post-combustion and oxy-combustion in thermal power plant for $\mathrm{CO}_{2}$ capture. Appl Therm Eng 2010;30:53-62.

[3] Toftegaard MB, Brix J, Jensen PA, Glarborg P, Jensen AD. Oxy-fuel combustion of solid fuels. Prog Energ Combust Sci 2010;36:581-625.

[4] Stanger R, Wall T. Sulphur impacts during pulverised coal combustion in oxy-fuel technology for carbon capture and storage. Prog Energ Combust Sci 2011;37:69-88.

[5] Tan Y, Jia L, Wu Y, Anthony EJ. Experiences and results on a 0.8 MWth oxy-fuel operation pilot-scale circulating fluidized bed. Appl Eng 2012;92:343-7.

[6] Myöhänen K, Hyppänen T, Pikkarainen T, Eriksson T, Hotta A. Near Zero $\mathrm{CO}_{2}$ Emissions in Coal Firing with Oxy-Fuel Circulating Fluidized Bed Boiler. Chem Eng Technol 2009;32:355-363.

[7] Czakiert T, Sztekler K, Karski S, Markiewicz D, Nowak W. Oxy-fuel circulating fluidized bed combustion in a small pilot-scale test rig. Fuel Process Technol 2010;91:1617-1623.

[8] Jia L, Tan Y, Wang C, Anthony EJ. Experimental Study of Oxy-Fuel Combustion and Sulfur Capture in a Mini-CFBC. Energy Fuels 2007;21:3160-4.

[9] Jia L, Tan Y, Anthony EJ. Emissions of $\mathrm{SO}_{2}$ and NOx during Oxy-Fuel CFB Combustion Tests in a Mini-Circulating Fluidized Bed Combustion Reactor. Energy Fuels 2010;24:910-5. 
[10] Liljedahl GN, Turek DG, Nsakala NY, Mohn NC, Fout TE. Alstoms OxygenFired CFB Technology Development Status for $\mathrm{CO}_{2}$ Mitigation. $31^{\text {st }}$ International Technical Conference on Coal Utilization and Fuel Systems, Clearwater, Florida, USA, May 21-25, 2006.

[11] Myohanen K, Hyppanen T, Pikkarainend T, Eriksson T, Hotta A. Near Zero CO2 Emisssions in Coal Firing with Oxy-fuel Circulating Fluidized Bed Bolier. Chem Eng Technol 2009;32:355-63.

[12] Varonen M. 4MWth Oxy-CFB Test Runs. $63^{\text {rd }}$ IEA FBC Metting, Ponferrada, Spain, November 29-30, 2011

[13] Jia L, Tan Y, McCalden D, Wu Y, He I, Symonds R, Anthony EJ. Commissioning of a $0.8 \mathrm{MW}_{\text {th }}$ CFBC for oxy-fuel combustion. Int J Greenhouse Gas Control 2011;doi:10.1016/j.ijggc.2011.10.009.

[14] Lupion M, Navarrete B, Otero P, Cortés VJ. Experimental Programme in CIUDEN. $\mathrm{CO}_{2}$ Capture Technology Development Plant for Power Generation. Chem Eng Res Des 2011;89:1494-500.

[15] García-Labiano F, Rufas A, de Diego LF, de las Obras-Loscertales M, Gayán P, Abad A, Adánez J. Calcium-based sorbents behaviour during sulphation at oxy-fuel fluidised bed combustion conditions. Fuel 2011;90:3100-3108.

[16] de Diego LF, de las Obras-Loscertales M, García-Labiano F, Rufas A, Abad A, Gayán P, Adánez J. Characterization of a limestone in a batch fluidized bed reactor for sulfur retention under oxy-fuel operating conditions. Int J Greenhouse Gas Control 2011;5:1190-1198.

[17] García-Labiano F, Hampartsoumian E, Williams A. Determination of sulphur release and its kinetics in rapid pyrolysis of coal. Fuel 1995;74:1072-9.

[18] Anthony EJ, Granatstein DL. Sulfation phenomena in fluidized bed combustion systems. Prog Energ Combust Sci 2001;27:215-236.

[19] Adánez J, García-Labiano F, Abanades JC, de Diego LF. Methods for characterization of sorbents used in fluidized bed boilers. Fuel 1994;73:355-62.

[20] Lyngfelt A, Leckner B. Sulphur capture in fluidised bed combustors: temperature dependence and lime conversion. Journal Institute Energy 1989:62-72. 
[21] Lin W. Interactions between $\mathrm{SO}_{2}$ and $\mathrm{NO}_{\mathrm{x}}$ emissions in fluidised bed combustion of coal. PhD Thesis. Delft University, The Netherlands, 1994.

[22] Fuertes AB, Artosa V, Pisa JJ, Marbána G, Palacios JM. Sulphur retention by ash during fluidized bed combustion of bituminous coals. Fuel 1992;71:507- 511.

[23] de Diego LF, Adánez J, Gayán P. Modelling and simulation of the sulphur retention in circulating fluidized bed combustors. Chem Eng Sci 1996;51:30773082.

[24] Manovic V, Grubor B, Loncarevic D. Modeling of inherent $\mathrm{SO}_{2}$ capture in coal particles during combustion in fluidized bed. Chem Eng Sci 2006;61:1676-85.

[25] Abanades JC, de Diego LF, García-Labiano F, Adánez J. Residual Activity of Sorbent Particles with a Long Residence Time in a CFBC. AIChE Journal 2000;46:1888-93.

[26] Mattisson T, Lyngfelt A. A Sulfur Capture Model for Circulating Fluidized-Bed Boilers. Chem Eng Sci 1998;53:1163-73.

[27] Lyngfelt A, Leckner B. Residence time distribution of sorbent particles in a circulating fluidized bed boiler. Powder Technol 1992;70:285-92.

[28] Lyngfelt A, Bergqvist D, Johnsson F, Amand LE, Leckner B. Dependence of sulphur capture performance on air staging in a $12 \mathrm{MW}$ circulating fluidized bed boiler. Second International Symposium on Gas Cleaning at High Temperature, Cuilford, UK, September 1993. 


\section{Captions for Tables}

Table 1. Analysis of coals and its ashes.

Table 2. Limestone characteristics.

Table 3. Tests carried out and experimental results obtained under oxy-fuel operating conditions.

Table 4. Tests carried out and experimental results obtained under enriched air operating conditions. 


\section{Captions for Figures}

Figure 1. Oxy-fuel Bubbling Fluidised Bed Combustor at ICB-CSIC. Measurements of temperature $(\mathrm{T})$ and pressure $(\mathrm{P})$.

Figure 2. Temperature and gas composition evolution during the start-up of the installation until reaching stable operating conditions.

Figure 3. Thermodynamic equilibrium curve of $\mathrm{CaCO}_{3}$ calcination.

Figure 4. Comparison between the sulphur retentions obtained working under enriched air and oxy-fuel operating conditions in the BFB combustor. Calcining and noncalcining conditions in oxy-fuel combustion determined by thermodynamic equilibrium with the gas inlet composition.

Figure 5. Effect of temperature on the sulphur retention with Granicarb limestone under oxy-fuel operating conditions. $\mathrm{Ca} / \mathrm{S}=3 ; \mathrm{O}_{2} / \mathrm{CO}_{2}=35 / 65$. Calcining and non-calcining conditions determined by the thermodynamic equilibrium with the gas inlet composition.

Figure 6. Effect of the $\mathrm{Ca} / \mathrm{S}$ molar ratio on the $\mathrm{SO}_{2}$ retention working with lignite and anthracite in oxy-fuel combustion conditions at different temperatures. $*\left(\mathrm{O}_{2} / \mathrm{CO}_{2}: 35 / 65\right)$

Figure 7. Sulphur retention by coals ashes at different temperatures working with enriched air (circles) and oxy-fuel (triangles) combustion conditions.

Figure 8. Effect of the residence time of solids in the $\mathrm{BFB}$ on the $\mathrm{SO}_{2}$ emissions. 925 ${ }^{\circ} \mathrm{C}, \mathrm{O}_{2} / \mathrm{CO}_{2}=35 / 65, \mathrm{Ca} / \mathrm{S}=2$

Figure 9. Sulphation conversion of the Granicarb limestone in a TGA during long reaction time. $\mathrm{dp}=0.3-0.5 \mathrm{~mm}, 3000 \mathrm{vppm} \mathrm{SO} 2,900{ }^{\circ} \mathrm{C}$, and $60 \mathrm{vol} . \% \mathrm{CO}_{2}$ 
Table 1. Analysis of coals and its ashes.

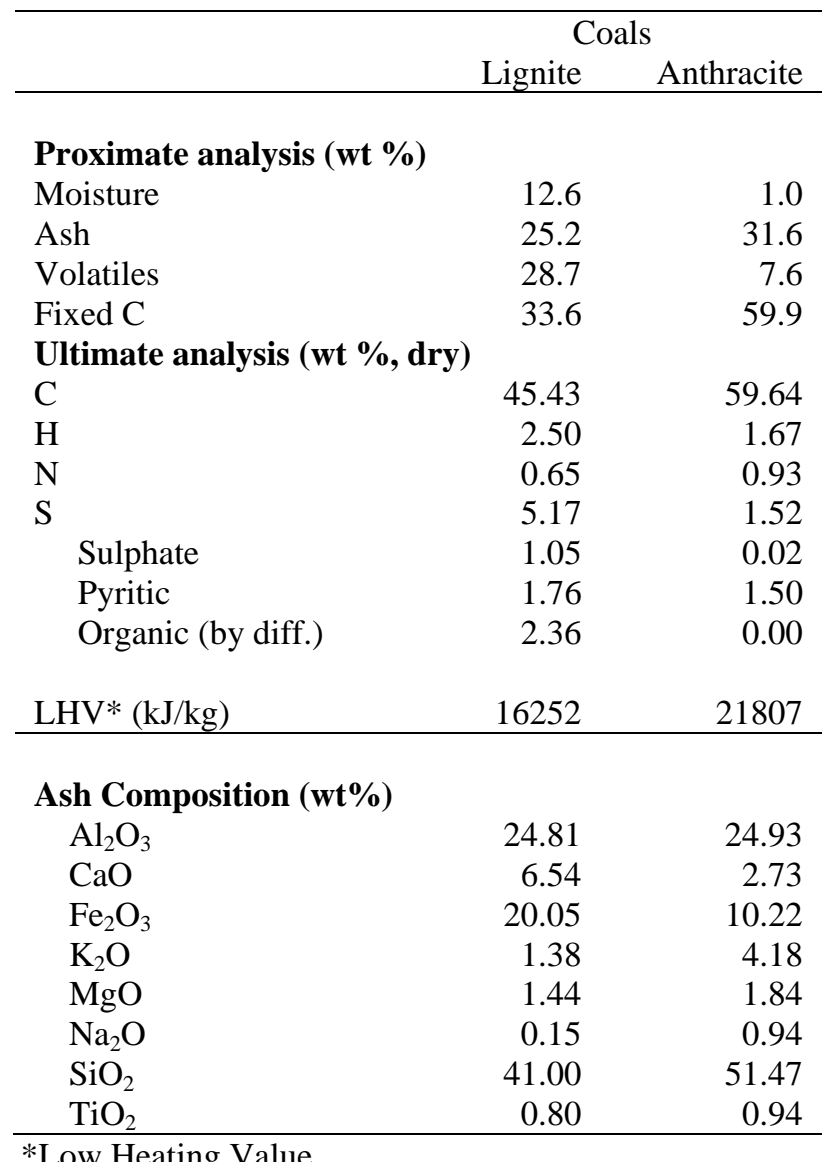


Table 2. Limestone characteristics.

\begin{tabular}{lr}
\hline Composition (wt \%) & \\
$\mathrm{CaCO}_{3}$ & 97.1 \\
$\mathrm{MgCO}_{3}$ & 0.2 \\
$\mathrm{Na}_{2} \mathrm{O}$ & 1.1 \\
$\mathrm{SiO}_{2}$ & $<0.1$ \\
$\mathrm{Al}_{2} \mathrm{O}_{3}$ & $<0.1$ \\
$\mathrm{Fe}_{2} \mathrm{O}_{3}$ & $<0.1$ \\
& \\
Porosity (\%) & \\
$\quad$ Raw & 3.7 \\
$\quad$ Calcined* & 49 \\
\hline
\end{tabular}

* Calcined in $\mathrm{N}_{2}$ atmosphere at $900{ }^{\circ} \mathrm{C}$ during 10 minutes. 
Table 3. Tests carried out and experimental results obtained under oxy-fuel operating conditions.

\begin{tabular}{|c|c|c|c|c|c|c|}
\hline Exp. & $\mathrm{Ca} / \mathrm{S}$ & $\mathrm{T}\left({ }^{\circ} \mathrm{C}\right)$ & $\begin{array}{c}\mathrm{O}_{2} / \mathrm{CO}_{2} \\
(\%)\end{array}$ & $\begin{array}{l}\mathrm{O}_{2} \text { in } \\
\text { flue gas } \\
\text { (\% d.b) }\end{array}$ & $\begin{array}{c}\mathrm{SO}_{2} \\
\text { emitted } \\
\left(\mathrm{ppm} / \mathrm{kW}_{\mathrm{th}}\right)\end{array}$ & $\begin{array}{l}\text { Power } \\
\left(\mathrm{kW}_{\text {th }}\right)\end{array}$ \\
\hline \multicolumn{7}{|l|}{ Lignite } \\
\hline OX-1 & 0 & 800 & $27 / 73$ & 3.9 & 3028 & 2.4 \\
\hline OX-2 & 0 & 850 & 27 / 73 & 3.8 & 3050 & 2.4 \\
\hline OX-3 & 0 & 900 & 27 / 73 & 3.9 & 3147 & 2.4 \\
\hline OX-4 & 0 & 950 & $27 / 73$ & 3.1 & 3234 & 2.5 \\
\hline OX-5 & 2 & 800 & 27 / 73 & 3.8 & 2439 & 2.4 \\
\hline OX-6 & 2 & 850 & 27 / 73 & 3.0 & 2180 & 2.5 \\
\hline OX-7 & 2 & 900 & 27 / 73 & 3.7 & 1486 & 2.4 \\
\hline OX-8 & 2 & 925 & $27 / 73$ & 3.7 & 1427 & 2.4 \\
\hline OX-9 & 2 & 950 & 27 / 73 & 3.7 & 1782 & 2.4 \\
\hline OX-10 & 2 & 925 & 35 / 65 & 3.6 & 1405 & 3.2 \\
\hline OX-11 & 3 & 850 & $35 / 65$ & 5.0 & 1843 & 3.1 \\
\hline OX-12 & 3 & 875 & 35 / 65 & 4.1 & 1196 & 3.2 \\
\hline OX-13 & 3 & 900 & 35 / 65 & 3.8 & 770 & 3.2 \\
\hline OX-14 & 3 & 925 & 35 / 65 & 3.5 & 828 & 3.2 \\
\hline OX-15 & 3 & 950 & 35 / 65 & 4.3 & 1123 & 3.2 \\
\hline \multicolumn{7}{|c|}{ Anthracite } \\
\hline OX-16 & 0 & 850 & 35 / 65 & 4.3 & 778 & 3.4 \\
\hline OX-17 & 0 & 900 & 35 / 65 & 3.9 & 771 & 3.5 \\
\hline OX-18 & 0 & 950 & 35 / 65 & 3.8 & 795 & 3.5 \\
\hline OX-19 & 2 & 850 & 35 / 65 & 4.3 & 592 & 3.4 \\
\hline OX-20 & 2 & 900 & 35 / 65 & 3.8 & 351 & 3.5 \\
\hline OX-21 & 2 & 925 & 35 / 65 & 3.6 & 332 & 3.5 \\
\hline OX-22 & 2 & 945 & 35 / 65 & 3.7 & 400 & 3.5 \\
\hline OX-23 & 2 & 970 & 35 / 65 & 3.6 & 507 & 3.5 \\
\hline OX-24 & 3 & 820 & 35 / 65 & 4.0 & 585 & 3.5 \\
\hline OX-25 & 3 & 850 & 35 / 65 & 3.8 & 533 & 3.5 \\
\hline OX-26 & 3 & 875 & 35 / 65 & 3.6 & 408 & 3.5 \\
\hline OX-27 & 3 & 900 & 35 / 65 & 3.5 & 293 & 3.5 \\
\hline OX-28 & 3 & 900 & 35 / 65 & 3.4 & 266 & 3.5 \\
\hline OX-29 & 3 & 925 & 35 / 65 & 3.5 & 305 & 3.5 \\
\hline OX-30 & 3 & 925 & 35 / 65 & 3.7 & 268 & 3.5 \\
\hline OX-31 & 3 & 940 & 35 / 65 & 3.6 & 330 & 3.5 \\
\hline OX-32 & 3 & 950 & 35 / 65 & 3.2 & 369 & 3.6 \\
\hline OX-33 & 3 & 970 & 35 / 65 & 3.7 & 437 & 3.5 \\
\hline
\end{tabular}


Table 4. Tests carried out and experimental results obtained under enriched air operating conditions.

\begin{tabular}{ccccccc}
\hline Exp. & $\mathrm{Ca} / \mathrm{S}$ & $\begin{array}{c}\mathrm{T} \\
\left({ }^{\circ} \mathrm{C}\right)\end{array}$ & $\begin{array}{c}\mathrm{O}_{2} / \mathrm{CO}_{2} \\
(\%)\end{array}$ & $\begin{array}{c}\mathrm{O}_{2} \text { in } \\
\text { flue gas } \\
(\% \text { d.b) }\end{array}$ & $\begin{array}{c}\mathrm{SO}_{2} \text { emitted } \\
\left(\mathrm{ppm} / \mathrm{kW}_{\mathrm{th}}\right)\end{array}$ & $\begin{array}{c}\text { Power } \\
(\mathrm{kW} \text { th }\end{array}$ \\
\hline Lignite & & & & & & \\
A-1 & 0 & 800 & $27 / 73$ & 5.0 & 2974 & 2.3 \\
A-2 & 0 & 850 & $27 / 73$ & 4.0 & 3153 & 2.4 \\
A-3 & 0 & 900 & $27 / 73$ & 4.7 & 3227 & 2.3 \\
A-4 & 0 & 950 & $27 / 73$ & 4.0 & 3096 & 2.4 \\
\hline A-5 & 2 & 800 & $27 / 73$ & 4.4 & 1238 & 2.3 \\
A-6 & 2 & 850 & $27 / 73$ & 4.6 & 932 & 2.3 \\
A-7 & 2 & 900 & $27 / 73$ & 4.5 & 1179 & 2.3 \\
A-8 & 2 & 925 & $27 / 73$ & 4.6 & 1533 & 2.3 \\
A-9 & 2 & 950 & $27 / 73$ & 3.3 & 1895 & 2.4 \\
\hline Anthracite & & & & & & \\
A-10 & 0 & 850 & $35 / 65$ & 3.6 & 780 & 3.5 \\
A-11 & 0 & 900 & $35 / 65$ & 3.7 & 782 & 3.5 \\
\hline A-12 & 3 & 820 & $35 / 65$ & 4.0 & 447 & 3.5 \\
A-13 & 3 & 850 & $35 / 65$ & 3.8 & 176 & 3.5 \\
A-14 & 3 & 870 & $35 / 65$ & 3.6 & 174 & 3.5 \\
A-15 & 3 & 920 & $35 / 65$ & 3.7 & 238 & 3.5 \\
A-16 & 3 & 970 & $35 / 65$ & 3.6 & 360 & 3.5 \\
\hline
\end{tabular}




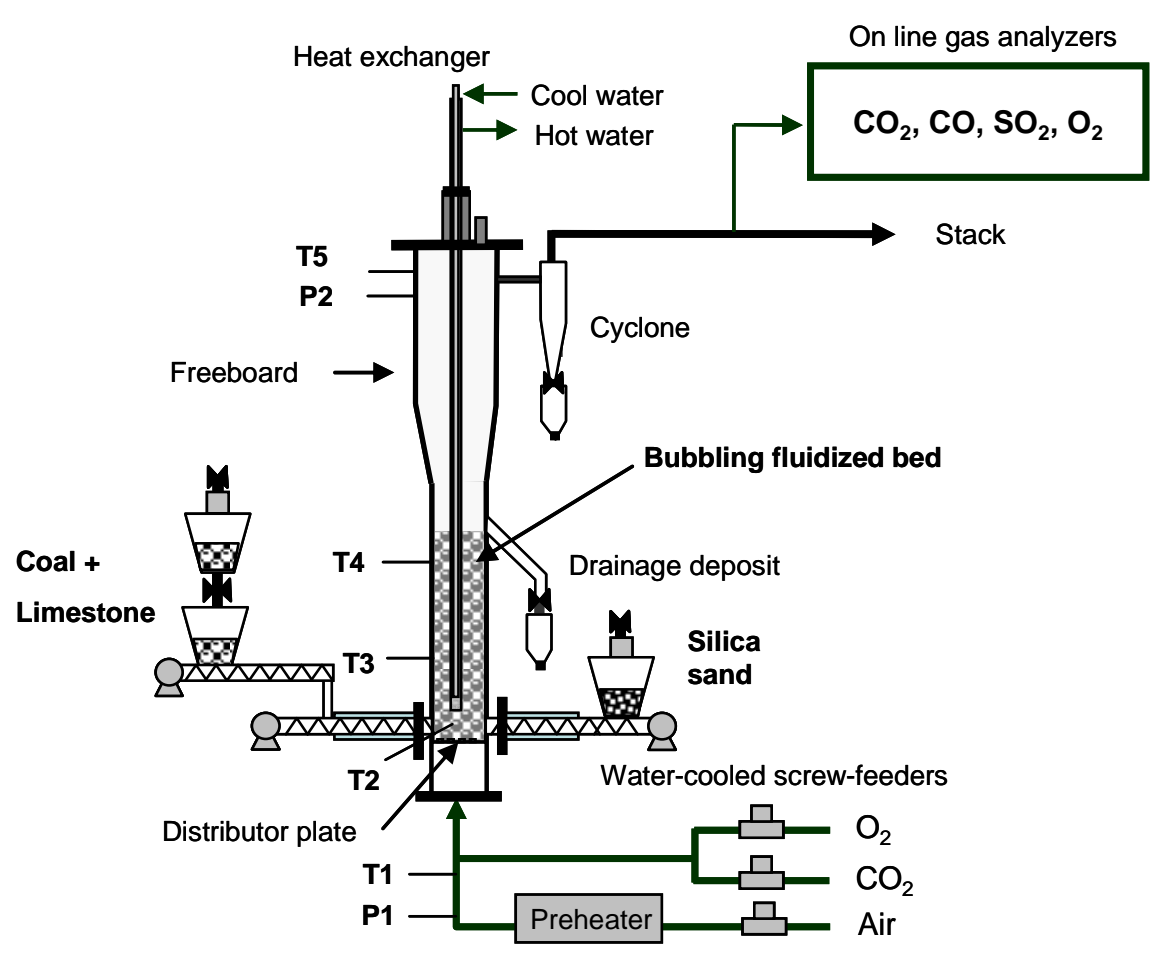

Figure 1. Oxy-fuel Bubbling Fluidised Bed Combustor at ICB-CSIC. Measurements of temperature $(\mathrm{T})$ and pressure $(\mathrm{P})$. 


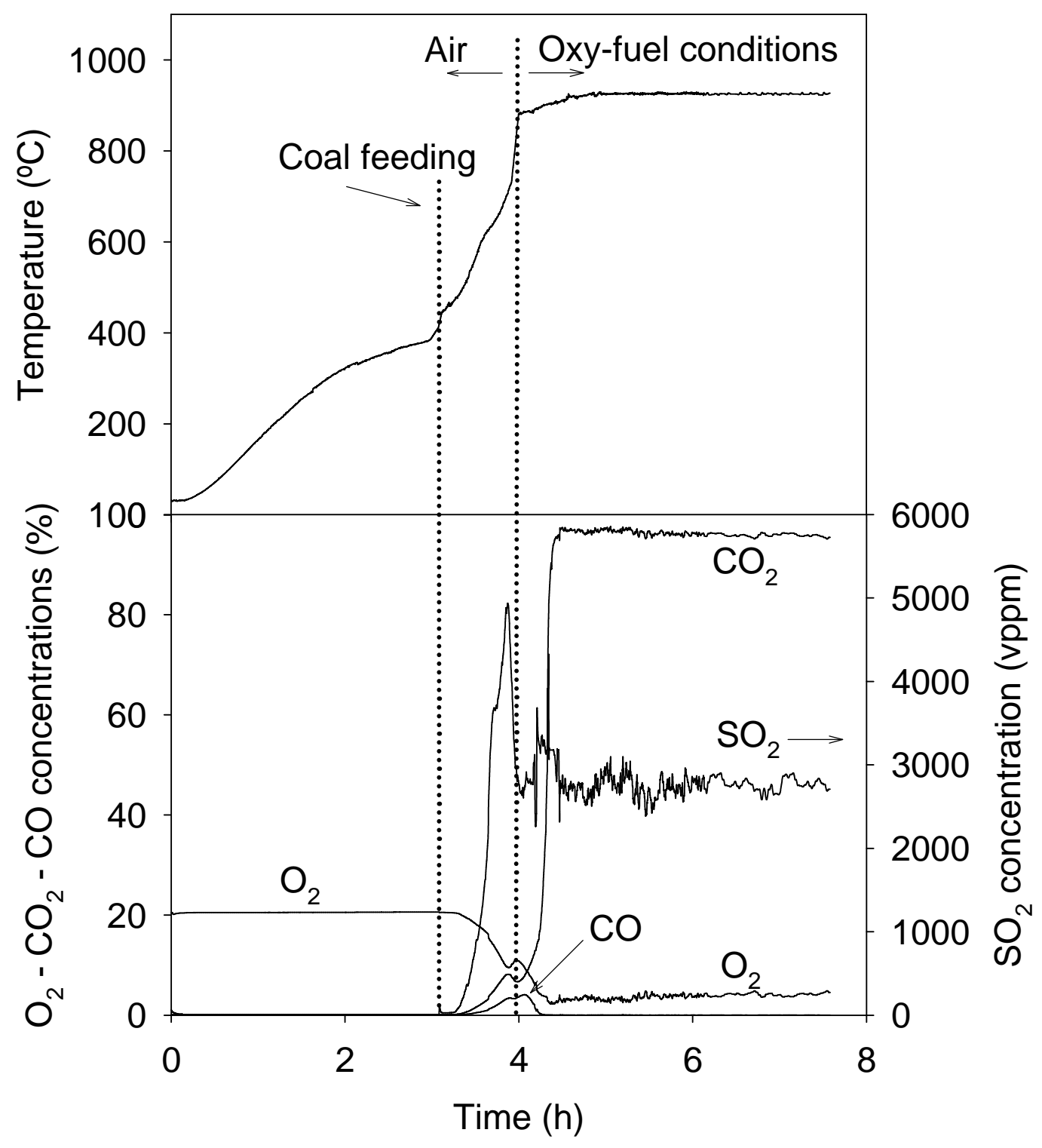

Figure 2. Temperature and gas composition evolution during the start-up of the installation until reaching stable operating conditions. 


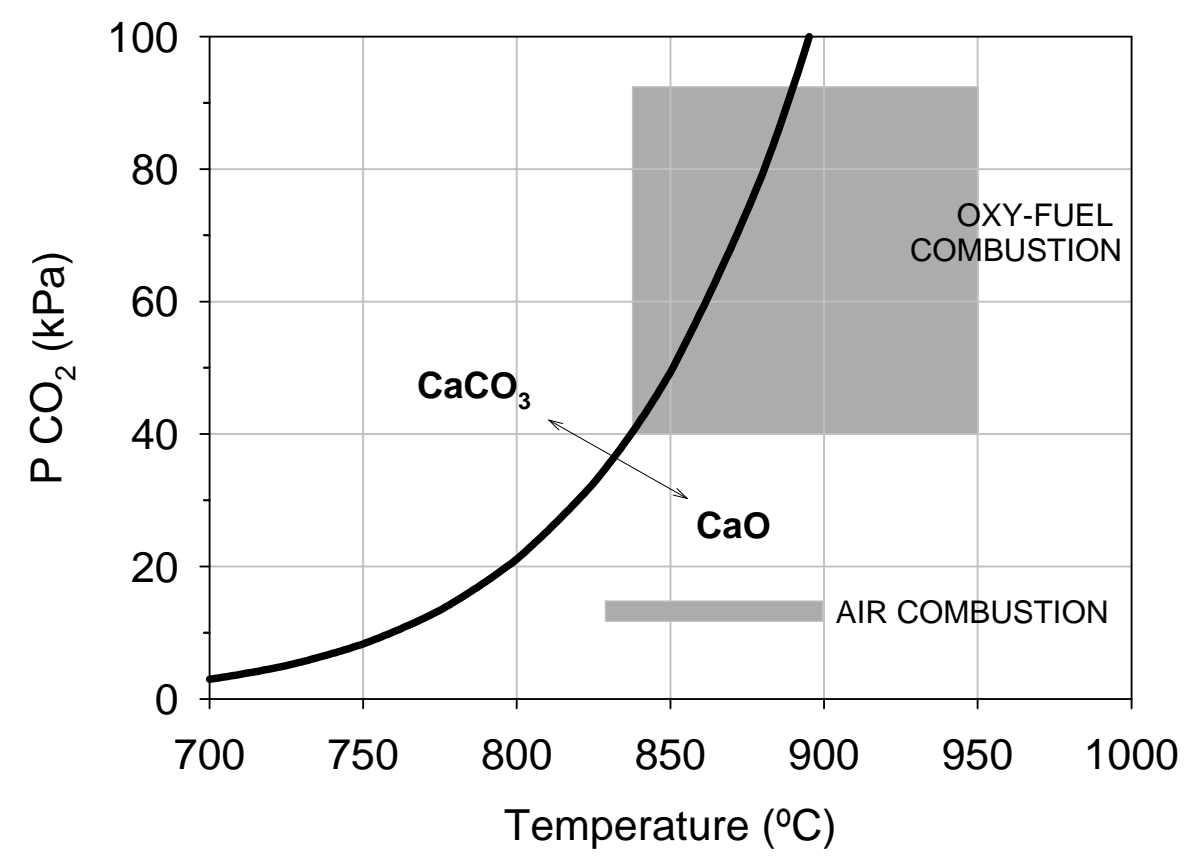

Figure 3. Thermodynamic equilibrium curve of $\mathrm{CaCO}_{3}$ calcination. 

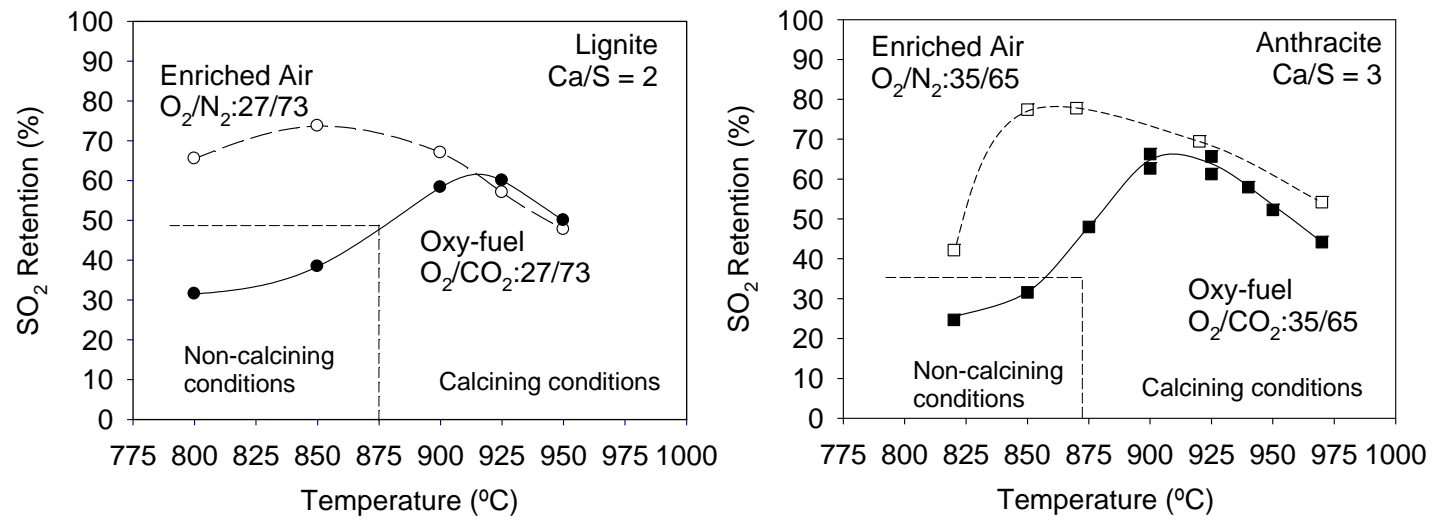

Figure 4. Comparison between the sulphur retentions obtained working under enriched air and oxy-fuel operating conditions in the BFB combustor. Calcining and noncalcining conditions in oxy-fuel combustion determined by thermodynamic equilibrium with the gas inlet composition. 


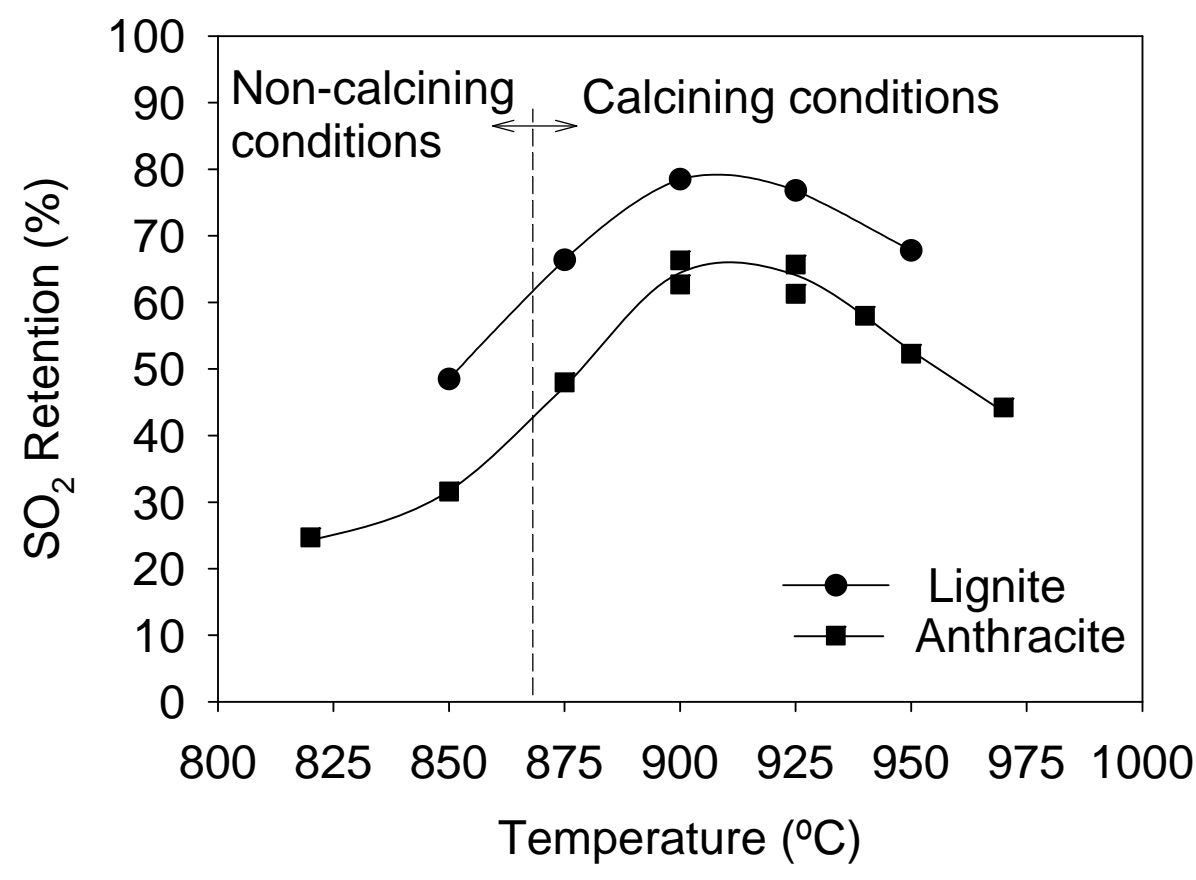

Figure 5. Effect of temperature on the sulphur retention with Granicarb limestone under oxy-fuel operating conditions. $\mathrm{Ca} / \mathrm{S}=3 ; \mathrm{O}_{2} / \mathrm{CO}_{2}=35 / 65$. Calcining and non-calcining conditions determined by the thermodynamic equilibrium with the gas inlet composition. 

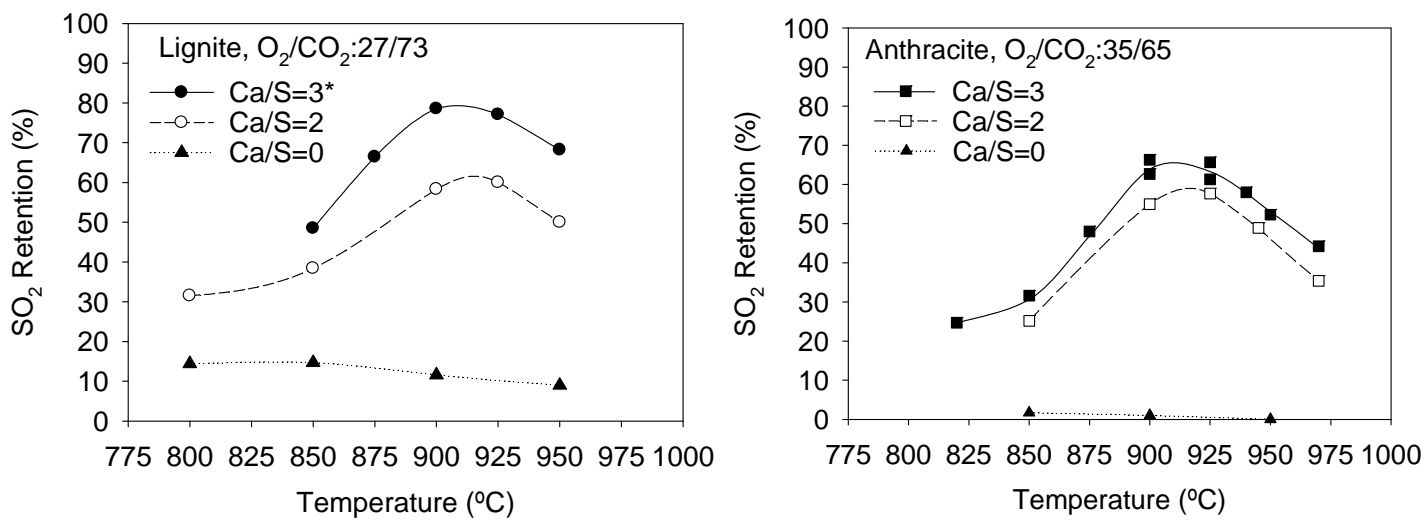

Figure 6. Effect of the $\mathrm{Ca} / \mathrm{S}$ molar ratio on the $\mathrm{SO}_{2}$ retention working with lignite and anthracite in oxy-fuel combustion conditions at different temperatures. $*\left(\mathrm{O}_{2} / \mathrm{CO}_{2}: 35 / 65\right)$ 


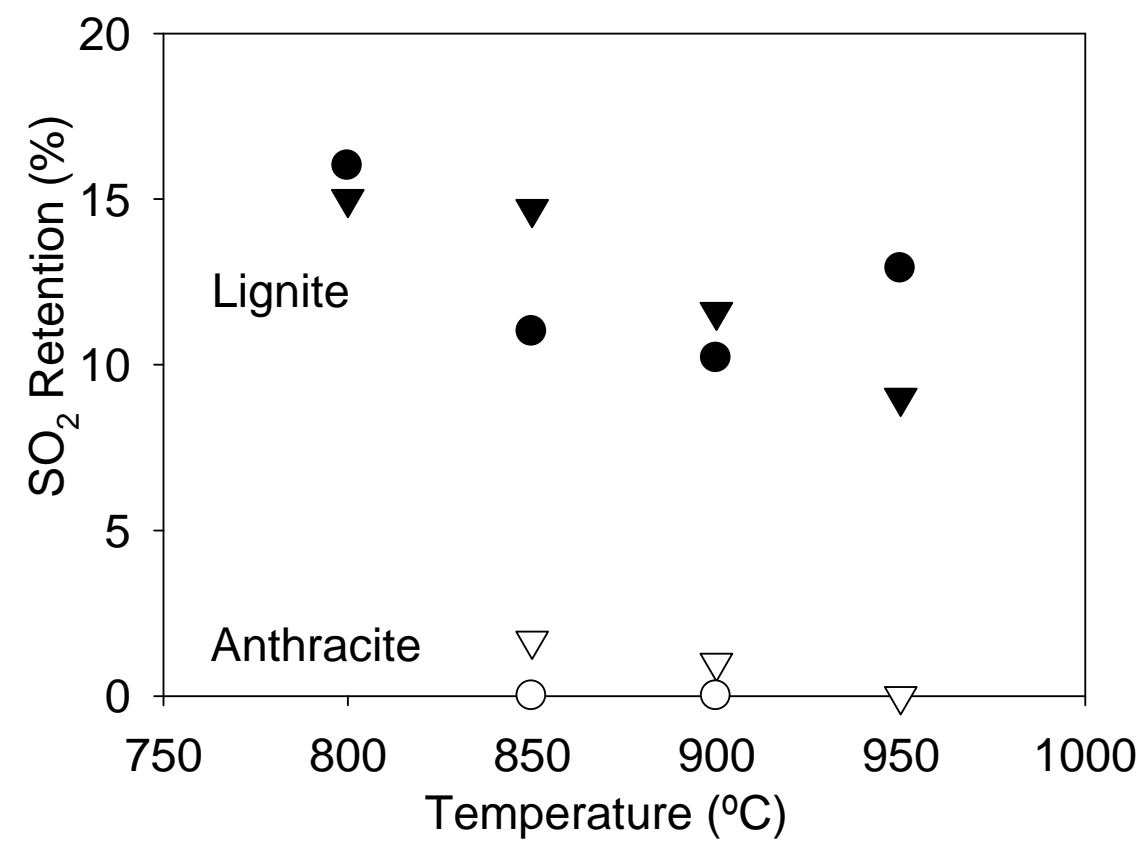

Figure 7. Sulphur retention by coals ashes at different temperatures working with enriched air (circles) and oxy-fuel (triangles) combustion conditions. 


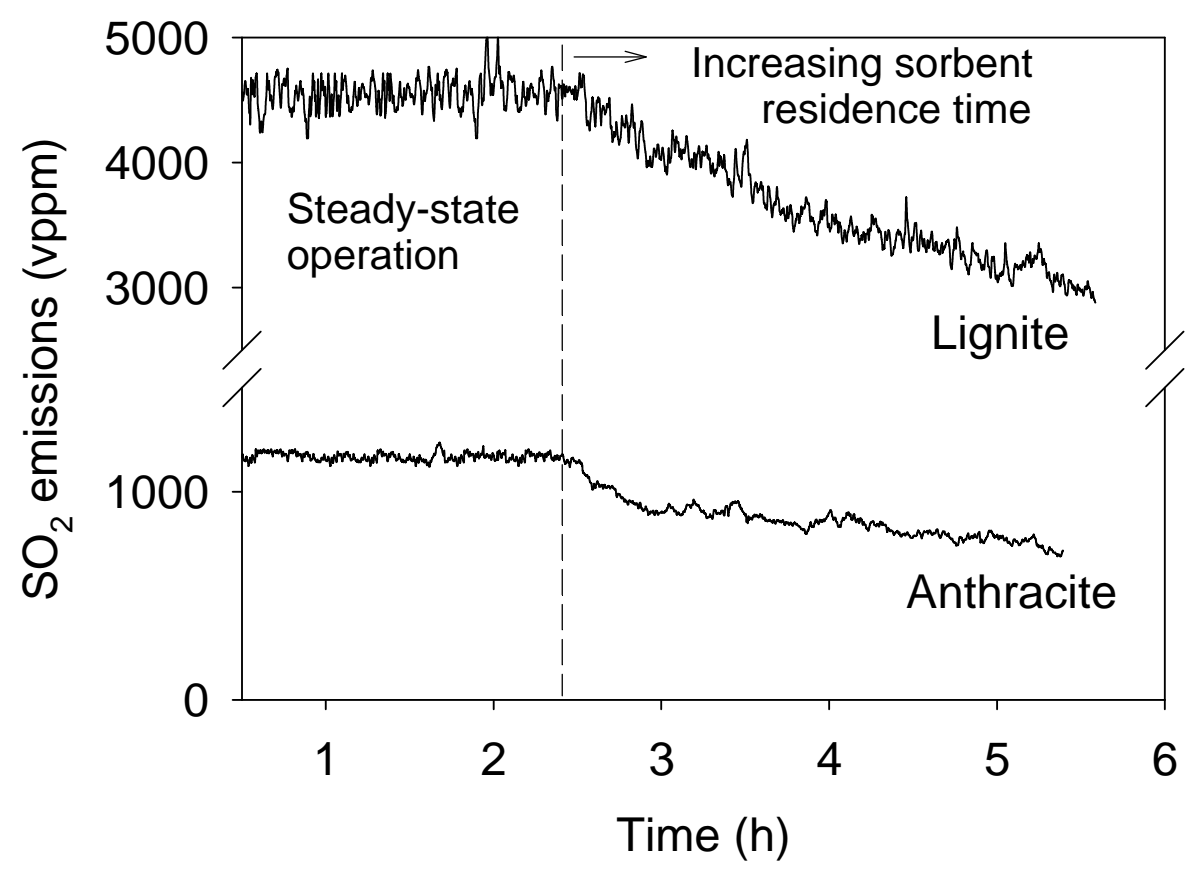

Figure 8. Effect of the residence time of solids in the $\mathrm{BFB}$ on the $\mathrm{SO}_{2}$ emissions. 925 ${ }^{\circ} \mathrm{C}, \mathrm{O}_{2} / \mathrm{CO}_{2}=35 / 65, \mathrm{Ca} / \mathrm{S}=2$ 


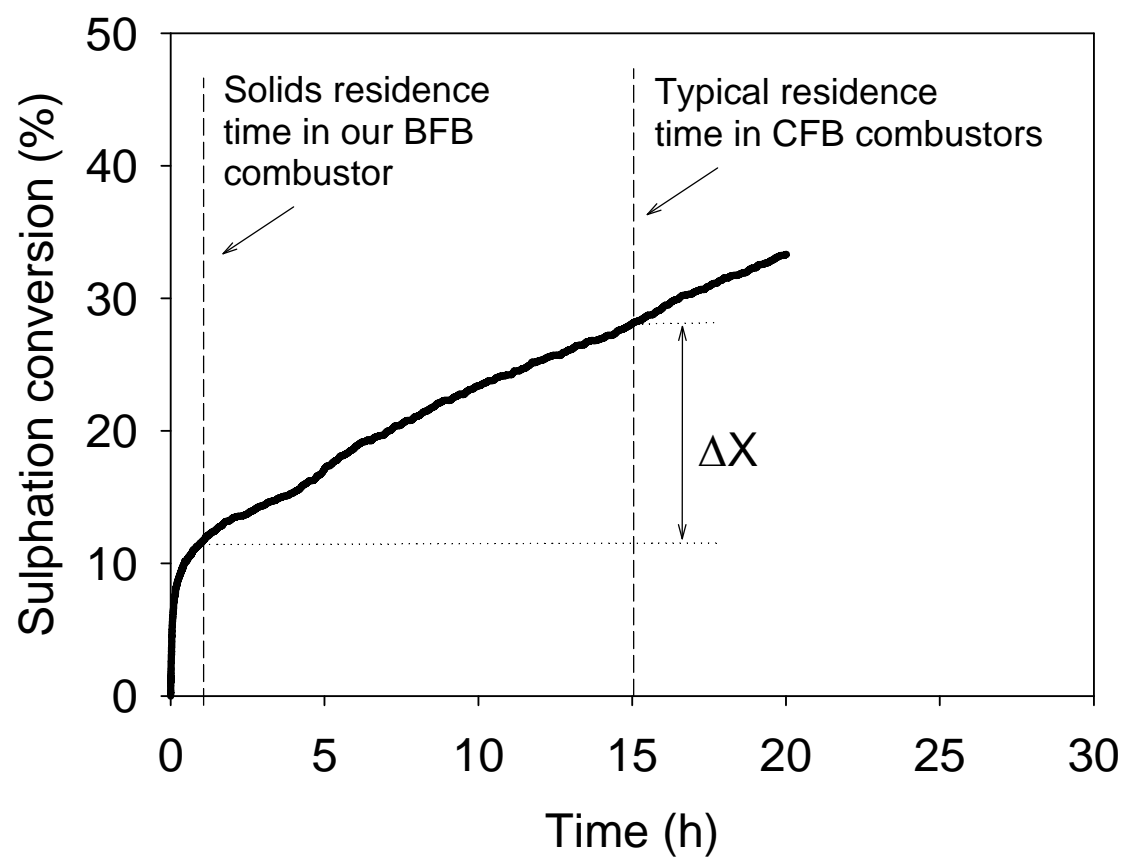

Figure 9. Sulphation conversion of the Granicarb limestone in a TGA during long reaction time. $\mathrm{dp}=0.3-0.5 \mathrm{~mm}, 3000 \mathrm{vppm} \mathrm{SO}_{2}, 900{ }^{\circ} \mathrm{C}$, and 60 vol. $\% \mathrm{CO}_{2}$ 